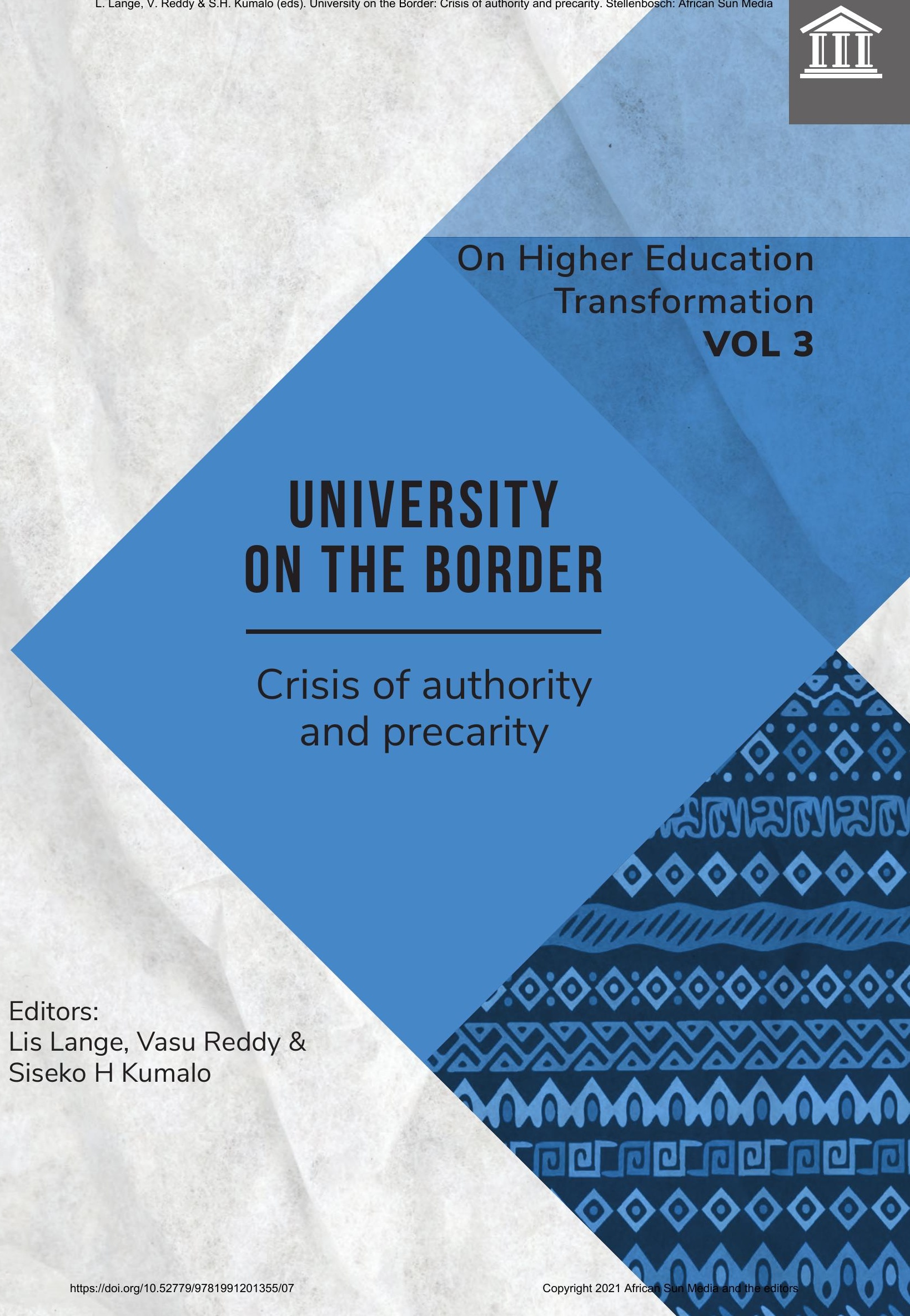




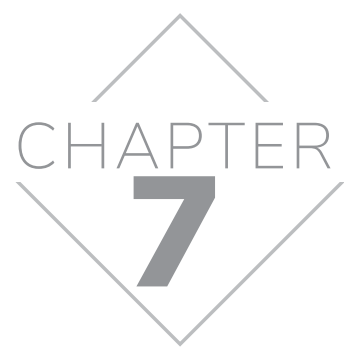

\title{
Precarious Authority and the Future of the University
}

\author{
Siseko H. Kumalo es Vasu Reddy
}

\section{INTRODUCTION}

The University in flux is a central thread running throughout this volume. Fuelled, to an extent, by the relations between the structure of economic and social life which are in turn influenced by local and global concerns, the University is shaped by variegated contexts that amplify the need for change. More specifically, a reimagining of South African universities is constitutive of a struggle contingent on the trajectories of past, present and future conceptions of the University in our context. University on the Border motivates for moving beyond the narrow confines of a topic and thematic, framing the debate rather as a problematic ${ }^{1}$ to reorient thinking about 'the University' as a discursive formation shaped in the current context, as a crisis of meaning (Wortham, 1999). The precarity of the contemporary university is detailed in the framing chapter in three ways. The first constitutes Lange's interpretation of the current situation as a challenge of authority, which in the second, is clarified by cursory analyses of the \#MustFall discourses developed

1 By "problematic" we suggest the framing of discourses and discursive conceptions of 'the University' in ways that challenge and contest the contemporary status quo, a move that facilitates the reorientation that was demanded by the students through their calls for \#FeesMustFall. 


\section{UNIVERSITY ON THE BORDER}

by both students and academics. In the third and final move, this precarity is detailed as the crisis of authority 'in perspective'; a perspective that curates a debate between local and universal knowledge framed as situated in apparent tension. This treatment of authority, as it relates to 'the University', highlights the 'idea of the university' and its plight - in Lange's analysis she borrows the concept of the 'idea of a university' from Bill Readings' foundational and provocative treatise, The University in Ruins (1996).

At a denotative level, "ruins" imply the remains of human-made architecture (perceived to be 'intact' structures now fallen into disrepair as a result of a lack of maintenance and/or destruction). But it is not just the physical that is at stake, but a collective architecture that requires interventions: material, intellectual and cultural. At a connotative level, 'ruins' simultaneously reference the possibility of reimagining and rethinking, which renews the question of discursive responsibility. ${ }^{2}$ Central to Readings' (1996) analysis in The University in Ruins are two guiding questions: how did the University arrive at its present critical state?; and what should be done to address this? Readings does not simply urge us to engage the ruins, but rather directs us to interrogate the challenges this 'state of being' generatively inspires. His argument proceeds through the identification of three dominant paradigms that have historically defined the evolution of the University; taking as its instructive examples, for the argument we develop here, a context that we are most aptly familiar with - the South African context and its University. The evolution of this institution is formulated by Readings who is instructive as to our thinking and argument, Kant's University of Reason, Humboldt's University of Culture, and the postmodern 'University of Excellence'.

The University becomes a locus of dissensus in Readings' schema of reading the interlocking complexities that the three paradigms pose. Improvements to its architecture in Readings' estimation entails the following intervention: a Bakhtinian dialogue should, in his view, replace Socratic dialogue. Socratic dialogue is about finding a precise answer to a universal question in a small group. At the same time, Bakhtinian dialogue foregrounds the value in iterative meanings, guarding against a precise answer, not simply to correct and silence 
but rather to extend the possibility of interpretation in its intertextuality and polyphony. In this respect, the Bakhtinian dialogue substantiates the critique offered by Friedman (in Chapter 4) when he challenges the call for fee-free higher education in the country. Bakhtinian dialogue in this regard suggests, that what we saw in this country were iterative propositions that sought to investigate the state's capacity of funding the poorest in the country. Simply, while our argument draws from yonder examples, we use the South African context to engage - in systematic detail - the challenges that bedevil 'the University of Excellence' as detailed by Readings. Such an approach is useful insofar as Lange, in Chapter 1, demonstrates how the country adopted this model at the dawn of democracy. This iterative, Bakhtinian, process attempted to move the country closer to the point of universal access to university education.

Readings' argument is emblematic of what the essays in this volume circuitously and/or directly addressed, namely the urgency for change; an urgency predicated on the crisis of authority that Lange detailed in Chapter 1 of this collection. The contributions, however, move beyond this to emphasise the preservation of thought in which the University becomes a site where justice replaces knowledge, where knowledge is assumed to be the only informing pedagogic principle. Our own submission holds that the two positions, knowledge and justice should be conceptually understood as informing each other, for there cannot be justice without knowledge and knowledge without justice locates the University in its paralysis without opportunity for moving beyond the border. In this respect, the principle of justice as a pedagogic device foregrounds, informs and implicitly undergirds the perspectival analysis that Lange developed in her third move, wherein she locates relevant knowledge in tension with the universal. Beyond framing the 'idea of the university', we maintain that the volume explores the notion of a 'precarious institution' in a time of crisis, a claim that is substantiated by what we view as a 'defiance to authority' represented by the student protest.

With the contributing authors in this collection thinking through a crisis created by the call for institutional and epistemic decolonisation, each chapter implicitly points to the notion of precarious authority while further raising the question of renewal, reimagining (and hence longevity as a counter 


\section{UNIVERSITY ON THE BORDER}

proposition to ruins) as it relates to the University, locally and globally. The idea of 'ruins' is a misnomer, since what the authors suggest in this volume is in effect the prospect of renewal, repair and change. As the 'university on the border' is characterised by what we deduce to be precarious authority and it is this precarity that allows us a new re-conception, ideas and generative spaces from which to theorise and practice, in our chapter, framed as the concluding remarks of this volume, we think through the ideas via three counts of precarity: the scramble for answers, the notion of citizenship and belonging as it relates to the power dynamics of pedagogy, and finally, how the University on the Border engages the question of canon formation and the vexed question of academic freedom.

\section{ANGUISH AND THE SEARCH FOR ANSWERS}

Precarity surfaces in three ways: First, as articulated in the volume's introduction, the contemporary university can be read as situated on the border, plunged into a pit by the actions of some students. (This is not to apportion blame, and we recognise that there are several interlocking reasons for the plight in which South African universities have found themselves; central here is the contested and shared histories of anti-racist struggles, including the apartheid and empire machinations). ${ }^{3}$ We understand this pit as the uncertainty and ongoing search for answers and potential solutions to conundrums in the sector that are entangled in a national higher education crisis shaped by what Drainville in Chapter 2 likened to the 1968 student protests. The demand for institutional decolonisation, curriculum transformation and the call for justice through the challenge that administrators put an end to a system of exclusion based on, for example, exorbitant fees and epistemic exclusions, places the University in the space of precarity. ${ }^{4}$ Our focus on precarity here

Cf. Bhambra, Gebrial and Nisancioglu, 2018.

4

We are reminded here, of Adam Habib's observation (Habib, 2019) when he recalls the challenge that was the task of balancing competing interests in the duties of administrating and institutional governance during the time of \#FeesMustFall at Wits University. Habib's concerns substantiate our claim for a multiplicity of interests and factors that led the sector to the crisis it found itself facing, during the time of \#MustFall. Habib (2019:79) suggests, "[all] of them [activists - both student and academic] effectively operated from the assumption that public education should be fully funded by the [State]; they have no thought, therefore, to the trade-offs between competing priorities.” 
is derived partly from the financial instability that ensued after the 2016 resolution of a fee moratorium. ${ }^{5}$ While it seemed that the student movements had won the battle, the struggles, however, continued, with contestations that challenged the perceived uniform identity of the University; what Lange frames as a contestation through the "defiance [of] excluded subjectivities". We are under no illusion, however, as we acknowledge that the \#MustFall movements revived historical debates on institutional culture transformation and curriculum revisions; a debate that has been topical in the academy since the dawn of democracy. We appreciate and acknowledge that educational theorists in the higher education studies field championed these debates since the early 2000s. ${ }^{6}$ Historically, calls for institutional transformation framed these debates, which saw the sector undergoing major changes instituted by the National Plan for Higher Education (Ministry of Education, 2001). These revisions saw the sector reduced from 36 universities to 24 by 2012 with the addition of the University of Mpumalanga and the Sol Plaatje University in 2014. The reduction of institutions sought to amalgamate the sector and address historical imbalances. In light of these sectoral reforms, we agree with Bozalek and Boughey (2012), who maintain that much of the work developed to address the challenges that plague the sector (mis)frames the problem and does not go far enough to address the inherent systemic and systematic inequalities and injustices.

We agree with Ali A Mazrui (1978:4) when he maintains that "colonial education did not merely produce teachers, politicians and administrators. It also produced a new literate culture which affected a much wider range of social variables". The literate culture that Mazrui (1978) refers to became a reality in the post-apartheid era in South Africa, and signalled something akin to what Wicomb, reproduced in Van der Vlies (2018 [1993]:65), suggested more than two decades ago when she wrote,

[we] need a radical pedagogy, a level of literacy that will allow our children to read works of literature that will politicise them into [...] awareness not only of

5 It is in reference to this move, a national fee moratorium, that we see the crisis into which universities were plunged all throughout the country. This move, we suggest, initiated the replacement of the Socratic Dialogue towards the Bakhtinian form that is iterative and revisionist.

6 For example, Bangeni and Kapp (2005); Boughey (2007); Boughey and McKenna (2011); Christie (2009); Luckett (2010); Ruth (2006); Shay (2015); Van Wyk and Higgs (2011). 


\section{UNIVERSITY ON THE BORDER}

power, but also of the equivocal, the ambiguous, and the ironic that is always embedded in power.

This consciousness came from - what we understand to be - a radical 'pedagogy of letters' that drove students to challenge the authority of the University and its power, a challenge staked as the rejection of the pervasive and continuing Eurocentric cultures that abound in the sector. The continuing prevalence of Eurocentric cultures (with priority given to northern epistemes) is the reason behind our contention for the relevance and subsequent use of Mazrui's (1978) analysis - four decades after its initial publication. Put differently, our argument emphasises the point that the political contestation - that required the redefinition of the African university, as proposed by Mazrui (1978) - continued to define the political moment that was \#MustFall in the South African context.

Deploying Nancy Fraser's work on 'injustice' and her notion of “misframing”, Bozalek and Boughey (2012) analyse the categories established during the mergers of institutions, which gave the higher education sector its current shape. Students subsequently challenged these amalgamations that sought to address the problem of inequality without substantive results, for instance, at the University of Cape Town (UCT) through the \#RhodesMustFall campaign. The mergers and amalgamations created three distinct categories of universities, with historically white universities (HWUs) constituting the bulk of what became known as 'traditional universities' (Bozalek \& Boughey, 2012:695). Along with the traditional universities, the Ministry of Education established Universities of Technology and Comprehensive Universities. These sectoral adjustments were in line with the aims and objectives of the democratic regime post-1994, which framed higher education as a social institution that would remedy historical injustices; an ideal articulated in the White Paper 3 of 1997 (Department of Education, 1997). The contributors to this volume raise implicitly an important interrogation of this ideal's successes with much of the analyses pointing to the unchanging and contested status of higher education in the country. We premise this claim on the reality of decolonial work (in its political and intellectual domains) that is now being undertaken in higher education institutions across the country. Much of this work (Heleta, 2016; Kumalo, 2018a; Seepe, 2017) points to the reality that the structure of higher 
education in the country still favours what became known as 'traditional universities' following the restructuring of the sector. We suggest that this reality may lead André Keet, Willy Nel and Sahar D. Sattarzadeh in Chapter 3, to frame the \#MustFall protests as a call for the democratisation of the University. Historically, much of the visible unrest witnessed in the sector, as the media presented, had been confined to historically black universities (HBUs) and Universities of Technology. In the wake of the protests that broke out during the 2015-2016 academic years, the 'traditional university' experienced, for the first time, protests on its campuses. The historical stability of HWUs derived from institutional autonomy that resulted in financial reserves was disturbed in 2015. An ethical question arises from this observation: how the ordinary citizen should understand the South African state and its conception and treatment of the University which, arguably, is only responsive when instability and protest rock the 'traditional university'. This question leads us again to Mazrui's (1978:268) insightful analysis when he writes that "[perhaps] the most fundamental political problems confronting African countries are reducible to two crises - the crisis of national integration and the crisis of political legitimacy". He goes further to suggest that "[but] even if the university has its own problems of ethnic cleavage [sic], can it not help in promoting a sense of shared political order in the wider society?" (Mazrui, 1978:273).

In our context, this question is premised on the differences that define HBUs and HWUs, with HBUs having encountered the challenges that student movements raised in the 2015 academic year - insufficient funding for undergraduates, inadequate student housing and accommodation and outsourcing, much earlier on. When these concerns were raised in the HBUs they received no or limited intervention from the State concerning sustainable resources that would effectively address these challenges as encountered in these institutions. Conversely, the HWUs, defined by apartheid nomenclature, was challenged by the \#Fallists plunging it into the pit that we understand to characterise the first count of precarity. This raises, considerable questions which require further investigation into the purported single higher education system established post-1994. Thus, engaging Mazrui's (1978) question, we suggest that this institution - the (South African) University - is unable to respond to the task of "promoting a sense of shared political order in the wider 


\section{UNIVERSITY ON THE BORDER}

society" because as an institution - the University in South Africa cannot yet be claimed as a national institution. ${ }^{7}$ Rather the differences that define the HBUs and the HWUs perpetuate the crisis of authority that Lange theorises, plunging the institution into a constant state of precarity. Owing to the State's response, or rather we should say, the failure to respond to the needs of the HBU, can we understand the sector to have truly been integrated into a single system that serves the needs of the country? The preceding claim that introduces the question mentioned above suggests that the state of precarity, with which we are confronted, stems from the sectoral inability to create and consolidate a unitary system - nearly three decades after democracy.

From a historical perspective, the work of Welsh and Savage heralded this first count of precarity. Writing about 'the University in divided societies', they argue that bringing together different people and ideologies into a space characterised by social divisions has catastrophic potential for the South African university (Welsh \& Savage, 1977:143). Welsh and Savage (1977:135) advance this claim after characterising the South African university sector as one that "mimicked rather than ameliorated the social divides at the height of apartheid". This assertion further underscores the question posed as to the reality of a unified and single higher education system. With the demise of apartheid, democracy necessitated a public university system that was transformed, and that would advance the knowledge economy while simultaneously managing competing imperatives and being responsive to the diverse and multiple needs of the economy and society.

Lebakeng, Phalane and Nase (2006) attest to the need for sectoral reform, which they frame as the 'Africanisation' of South African universities. Africanisation, as they articulate it, would have been a response to what they term "epistemicide" owing to the continued privilege that Eurocentric epistemic paradigms enjoy. Lebakeng, Phalane and Nase (2006) are echoed in Nyoka (2013) when he critiques social theory in South Africa, claiming that it is rooted in theoretical appropriations that continue to prize the epistemic status of Western knowledge as universal. The first account of precarity, which speaks to the uncertainty that characterises the contemporary university because of 
the scramble for answers strengthens the claim of the theoretical dependency observed by Lebakeng et al (2006) and Nyoka (2013). South Africa remains a pliable ground for northern scholars' data collection while undermining local researchers' capacity to develop their theoretical tools. The first count of precarity is therefore derived from the contestations that have characterised the higher education sector in South Africa since the dawn of democracy. Lange elegantly details this count of precarity when she characterises it as a space of anguish that is defined by the search for answers.

\section{PEDAGOGY, POWER AND CITIZENSHIP}

The precarious nature of the University is also derived from porous borders that challenge universal and totalising authority. This second count of precarity suggests a multitude of issues; however, we wish to pay attention to only two. The two elements to be considered under the second count of precarity are the role of power in pedagogy, and language contestations as a marker of citizenship and belonging. Through their actions, student movements revealed the provinciality of Eurocentric epistemic paradigms that have been mostly uncritically embraced by many in the South African academy which relies on theoretical appropriation. It is useful to note that these importations also define the pedagogic relationship, that continues to be framed along the lines of hierarchal rationalities derived from Eurocentric ideas about the University. The notion of epistemic humility proposed by decolonial scholars shifts the knowledge paradigm that locates the academic/ intellectual at the apex of the knowledge economy while relegating the student to a passive knower. While University on the Border, as a collection, provides the conceptual grammar with which to (re)think this paradigmatic shift that the student movements inaugurated, the \#Fallists gave us the physical lexis through their actions. In claiming that the \#Fallists gave us the physical lexis, we are in no way undermining or dismissing the intellectual contributions that they also made to the debate on decolonisation. We suggest that their actions instantiated the very need to (re)consider this conceptual grammar that had been the underlying bedrock of the University in our context; a need that inspired similar questions in contexts such as the United Kingdom. In what can be interpreted in one sense - which is by no means totalising - as the inversion of power relations, with vice-chancellors being forced to meet students on an 


\section{UNIVERSITY ON THE BORDER}

equal footing, ${ }^{8}$ decolonial praxis was enacted and challenged the University's universal authority. This inversion, presumably, is what García (2018:3) has in mind when he references the "geo- and body-politics and loci of enunciation", in his maintaining that

[i]t becomes more than an assumption when in the exhaustion of the episteme, border, and oppositional consciousness politics there emerges a predicament. The predicament is a performative a priori, which both indexes an inherently resistant and decolonial-in-character subject and registers a hegemonic macro-narrative of oppressor/oppressed. This is the translation when claims are made that it is possible to think outside and apart from the frame of hegemony and when incommensurability (e.g., two people at work) is pursued. The exhaustion of the episteme, border, and oppositional consciousness politics exposes limitations and indicates the difficulty in actually doing decolonial work.

Evident in the above perspective is the idea that the decolonial turn enables a performative gesture, especially in the context of how performances are wielded to negotiate public identities that are liminal and on the margin. This negotiation of marginal identities is predicated on securing ones' existence as a legitimate member of the polity - as a citizen, suggests how decolonial praxis facilitates democratisation in and through pedagogical strategies that challenge and contest the accepted/unquestioned dominant ideology. Our argument here acts as a rejoinder to Keet et al. in Chapter 3 of this volume. In this respect, the democratisation of the knowledge project, García's (2018) conception of the "geo- and body-politics and loci of enunciation" concurs with Wicomb and Van der Vlies's (2018 [1994]:105) observation that "[ideology] operates within discursive formations precisely because interdiscourse remains disguised, or rather is absorbed/forgotten in intradiscourse".

Further, \#Fallists contested and democratised the totalising claim of the point-zero position. They identified the setbacks of being subjected to an education that mimics northern training (in the Anglo-American tradition) in an African context. In defiance of an education characterised by what

8 In response to the shift in the knowledge paradigm that governed the University, institutional leadership took to securitisation and derailing efforts at institutional democratisation on the premise of security threats. See, for instance, Thepa (2016); cf. Habib (2016a, 2016b). 
Freire (1970) calls the "banking method", students actioned the converse 'problem-posing education'. \#Fallists' enactment of 'problem-posing education' challenged the totalising authority of the structure of knowledge in the 'Westernized university' (Grosfoguel, 2013). It agitated for democratisation, while legitimately allowing black/indigenous bodies to claim their citizenship in the city-state that is the University. Democratisation, in ourview, is a process, and from students' perspective was expressed as the urgency to be taught African thinkers, as a form of legitimating and establishing an African locus of thought and existence in an African university. In framing democratisation as a process, we acknowledge and appreciate the Badiouean framework used by Keet et al. (Chapter 3), when they reference \#MustFall-TheEvent. However, we differ slightly by way of locating this historical moment in the preceding shifts and changes that defined the sector since the early 2000s. By flagging this slight divergence, we concur with Lange, that the 'university on the border' is marked by generative conceptual disputes that facilitate new ways of thinking and doing. The insistence that students be taught African thinkers in an African university will be discussed as part of the third count of precarity wherein we analyse the underlying assumptions that inform canon formation in the precarious institution that is the 'university on the border'. Challenging the University's universal and totalising authority through decolonial praxis meant two things for the \#Fallists resisting Eurocentric epistemic paradigms through, for example or as mere interpretation, (a) inverting the power relations of pedagogy, and (b) democratising the canon by establishing its pluriversality.

As such, the porous borders of the 'university on the border' revealed the crisis of authoritative legitimacy, as those who had previously been defined as "abject subjects" (Kumalo, 2018b) had made their way into the University and were demanding equal political rights and the same recognition as those who had traditionally occupied the halls of learning in these institutions. Resisting Eurocentric epistemic paradigms through epistemic humility and the act of democratising the canon is denotative of decolonial praxis in action.

As indicated above, we wish to deal with two elements of the porous borders of the 'university on the border'. The second element speaks to the question of citizenship and belonging. The language of citizenship provides an important 


\section{UNIVERSITY ON THE BORDER}

framework to understand how subjects become recognised as socially legitimate and afforded rights and duties (Isin \& Turner, 2007; Turner, 2001). Discussing the desegregation of schools in South Africa during the late 1990s, Van Heerden (1999:67) claims that the requirement for integration leaves the incoming group without a "sense of community". This lack of belonging stems from the fact that the incoming group are made to feel alien, out of place and 'Othered's in their new environment. This placelessness in an institutional setting which has historically excluded Blackness/Indigeneity highlights the notion of abjection detailed by Kumalo (2018b) in his work on the role of HWU creating Natives of Nowhere. Placelessness, in this respect, resurrects the concept of being "unhomed" discussed by Kapp and Bangeni (2005:202) in a longitudinal study of students' negotiation of language, literacy and identity in a contemporary South African university. Considering placelessness as being unhomed, the erasure of Blackness/Indigeneity in HWUs and the impetus for decolonisation, it is necessary to inquire again about the inroads made by the state in creating a unified university sector in the country. This sense of belonging for some, which defines others as marginal and appendages that are tolerated (and contained) in Afrikaans and English institutions, highlights the precarity of the contemporary university in relation to who belongs and who is excluded. With South African society characterised by eleven official languages, each of which are recognised by the Constitution, it is necessary to query the status and legitimacy of the citizenship which each identity attempts to lay claim to in the 'university on the border'. The concept of language as a category that qualifies or denies one citizenship, a matter that is constitutive of the decolonial debates in higher education, reveals the notion of porous borders, defined by 'unwanted' and tolerated subjects who find themselves in the polis but excluded from the polity on the premise of their ethnic and racial identity. This sense of precarity may lead one to read Orwell's (2008) claim that "all are equal, but some are more equal than others" into the perspectives offered by contemporary contributors to the question and treatment of the category, 'language', in the decolonial debate. Citizenship and equality, aspirations that shape identity formation as the contributors of this volume implicitly discuss, point to a recurring theme in higher education literature-belonging. 
In his timeless analysis, Building a People's University in South Africa, Gregory Anderson (2002) points to this reality when he writes about the open admissions policy of the University of the Western Cape (UWC) in the 1980 s. Anderson (2002:50) writes,

[Much] of these resentments stem from what I have defined as the 'racial politics of scarce resources' between Coloured and African language students as 'entrenched notions' among students that discriminatory practices privileged one group to the disadvantage of the other continued to define their social reality.

In the context of the former Afrikaans universities that cling onto language as a means of disguising the deeply problematic and implicit racist conservation of white privilege as the right to culture and belonging, how are we to understand the place of Blackness/Indigeneity in these institutions? On another, deeper and philosophical, level how are we to read the continued use of bilingualism for academic purposes, specifically as it relates to citizenship and belonging? Is the paranoia of students at UWC still applicable in this contemporary context, where some students feel that others are privileged to their disadvantage? This question was raised by the \#Fallists in their claims for a just and equitable higher education system, which would signal the legitimacy of all citizens of the polis, defined here as the University on the Border. These linguistic contestations shaped the protests at Stellenbosch University and culminated in the short film \#Luister (Contraband Cape Town, 2015), which exposed an underlying culture that exacerbated racial differences of inclusion and exclusion along the lines of language.

The charge for monolingualism in the contemporary institution of higher learning in South Africa further inspires contemplation about the role of African languages (Zondi, 2020).$^{10}$ With English and Afrikaans as the dominant languages of instruction, a critical question arises; how do we understand the ideal of institutional Africanisation? The question of Africanisation is also fuelled by calls for decolonisation. As such, citizenship and belonging which

10 The article centralises Benedict Wallet Vilakazi's (1906-1947) poetry and argues that by resurrecting 'black archives', epitomised by revisiting the work of one iconic writer and scholar, Vilakazi, we could give further impetus to the prospect of intellectual efforts in African languages. See also Maseko and Vale (2016) and Mkhize (2016) who directly address the question of African languages in a decolonial paradigm. 


\section{UNIVERSITY ON THE BORDER}

are centred by the language debate suggest that the decolonial agenda is still fraught with incongruences and lacks definitional clarity. We should, however, highlight that inroads have been advanced in this respect when one considers the arguments made by Kumalo (2021) using the work of William Wellington Gqoba in the introductory essay to the volume. However, we should not be misunderstood as suggesting that decolonisation ought to be defined by an appeal to a nationalist project that is insular, inward-looking and dismissive of the global context in which we find ourselves. As Mazrui suggests, there is a need to define the aims of education in any society to derive maximum benefit from the educational enterprise, a suggestion framed in the following articulation (1978:285): “[The] most important factors behind Europe's imperial expansion could be put together in clusters - a cluster of economic motives and a cluster of cultural imperatives." The objective of deriving benefit from the educational enterprise is complicated by the place and value afforded to African languages, four decades ago; an attitude that is surely changing contemporarily. Mazrui (1978:299) frames the African languages debate as follows,

Students can study the technicalities of Bantu linguistic structure, but the study either of African languages or African literature in indigenous languages is still at best an aspiration at Makerere rather than an accomplished development. What is astonishing is that so many black intellectuals and scholars continue to regard this lack of seriousness about African languages as justified.

In South Africa, the justification is derived from the derision and dismissive attitudes that some white intellectuals continue to exhibit for African languages, a move that previously cajoled Black/Indigenous scholars into a dismissive state about the role of African languages, in the intellectual project. In sum, we wish to reiterate that we are not arguing for a nationalist focus that is parochial and essentialist. Rather we suggest further clarifications and nuanced perspectives in the project of decolonising the University, to entrench and legitimate the claims to citizenship of Blackness/Indigeneity in the University where language also holds a central purpose and function.

The second count of precarity, as it signals the porous borders of the University, rests on two elements, power and pedagogy as they give access to and legitimate citizenship and belonging. This second count of precarity 
stimulates deeper and more considered thought. The urgency for further speculation necessitates research that investigates these intricate facets such as the purported notion of a singular university sector. Following from the first count of precarity, we maintain that the classifications which saw some universities branded as 'traditional universities' played into the perpetuation of inequalities in a system fraught with numerous historical injustices. This claim contextualises the '(mis)framings' (Bozalek \& Boughey, 2012) and misdiagnoses which this volume addresses through analyses that think through and question the challenges which continue to plague higher education. We contend that these (mis)framings elide the systemic challenges which require attention if higher education is truly to become a social institution that redresses historical injustices.

\section{CANON CONSTITUTION}

Thirdly, we encounter precarity as it relates to canon formation. Canons are central to epistemic inclusivity in as much as it is about value determination that highlights the dichotomy between what is to be foregrounded and privileged and that which is to be minimised and thus erased. Canon is about closed communities, and central to this count of precarity is the question of what should be included in the curriculum. Simply put, how does the 'university on the border' decide what selections and choices are to be made, what is to be taught and more importantly, what informs this decision? With Lange's suggestion that "on the border, is a space of creativity and possibility but also of anguish and search", we concur with her framing and wish to emphasise the latter part of her diagnosis. We highlight the 'anguish and search' as a means of re-emphasising the first count of precarity characterised as a scramble for answers owing to the pit into which student actions plunged the University. The institutional responses that have attempted to suggest solutions to the challenges that students raised underscores this aspect. The struggle for answers in institutional responses takes the form, pattern and architecture of additive approaches to the call to decolonise the curriculum, teaching and learning. The debate on curriculum, teaching and learning, in decoloniality, has undervalued the centrality of the constituent elements of ontology (beyond the salience of epistemology) as it relates to canon formation. 


\section{UNIVERSITY ON THE BORDER}

To clarify the importance of ontology we consider Bhaskar's (2016) thoughts on transcendental realism and the philosophy of science. Bhaskar (2016:25) motivates for what he calls "ontology distinct from epistemology". By this Bhaskar advances a distinction between "philosophical ontology and scientific ontology" (2016:26). Scientific ontology can be understood as an ontic ontology or "irreducibly empirical a posteriori scientific" reality and philosophical ontology as "ontology formed by [a] transcendental argument from a specific epistemological premise" (Bhaskar, 2016:26). He explains this theoretical move (ontology distinct from epistemology) as "knowledge [that] is socially produced and changeable, but [...] is of (or about) things and structures that are existentially quite independent of us and our knowledge" (Bhaskar, 2016:25). Here Bhaskar allows for a distinction to be drawn between the actual and the real which produces a "three-tiered dynamic and transfactual form of dispositional realism" (2016:28) that enables us to observe (a) power as it is; (b) exercised; and its (c) manifestation or actualisation.

The three-tiered dispositional realism developed by Bhaskar (2016) better explains Archer's (2000) notion of a layered/stratified ontology, from which the debate on canon formation ought to proceed. Ontological recognition as it relates to curriculum, teaching and learning might be better understood in terms of Popkewitz and Brennan's $(1997,1998)$ argument which underlines the need to consider the social, political and economic factors that influence educational aspiration and attainment. These social factors come to light when proceeding from a position that targets the attainment of justice using Bhaskar's (2016:28) notion of a three-tiered dispositional realism in education and curriculation. Essentially, the 'university on the border' invites the question: Why do we teach $?^{11}$ The underlying assumptions that inform the response to this question will reveal the power dynamics at play in pedagogy, 'how' these dynamics are negotiated or exercised and 'how' they manifest. In this regard, Bhaskar (2016) reveals the centrality of ontology in the decolonisation of curriculum, teaching and learning.

The question of canon formation is doubly charged for the 'university on the border' from a historical perspective. In, The University in Ruins, Readings

11 It is important for us to note that this question acts as a rejoinder to the second consideration in this section, wherein we consider, through Mazrui (1978), the aims of education. 
(1996:5) argues that "[the] University, [...] no longer participates in the historical project for humanity that was the legacy of the Enlightenment: the historical project of culture." In the South African context, this claim can be contested for two reasons, firstly the University was never a centre of culture, ${ }^{12}$ which Readings (1996) and Lange term the Humboldtian university with Lange, in Chapter 1, framing this institution as "fundamentally a publicnational university responsible for the education of citizens unified through national culture". Defined by a history of division, oppression and injustice, South African society's constitutive elements were never inclined towards a national culture in a singular and homogenous way but rather one that recognised difference as a valuable attribute in contrast to an apartheid conception. One might conceive of national culture in relation to the former Afrikaans universities such as the Rand Afrikaans University, the University of the Orange Free State, the University of Pretoria and Stellenbosch University, to mention a few, where the promulgation of an Afrikaner Nationalist ethos with Afrikaans as a language dominating the teaching and learning paradigm constituted the predominant ethos. Noteworthy about these institutions is the role they played historically in sowing and sustaining division through allegiance to a narrow Afrikaner nationalist political ideology premised on racial prejudices, injustices and linguistic superiority. A stratified ontology, strengthened by Popkewitz and Brennan's (1997) theoretical tool of a 'social epistemology', which considers the social, political and economic factors that influence educational desire and attainment better situates the demand by Blackness/ Indigeneity for the decolonisation of higher education in our context. When read in tandem with Friedman (Chapter 4), the claim for decolonisation in this respect becomes a rich intellectual space for further theoretical developments that might respond to the socio-political realities of the country. As a response to this 'national culture', which signalled institutional collusion with the state, the former English universities - Rhodes University, UCT, and the University

12 However, it is important to note that universities were originally a 'steering mechanism' of an earlier social formation, socialising its elites, and functioning as one of the bearers of its knowledge and high culture (for example, Rustin, 2016). Thankfully, we are moving away from that limiting paradigm. Universities are now also increasingly today about the creation of a future for us all. Universities have a very important and ambitious aim ('a kind of social compact') directed towards producing scholars and graduates who really 'make a difference', both personally and professionally, to compete in a changing, 'troubled and messy' world. 


\section{UNIVERSITY ON THE BORDER}

of the Witwatersrand found themselves protesting state encroachment in internal institutional affairs. These institutional protests were formalised as the Academic Freedom Lectures and crowned by Thomas Benjamin Davie's remarks on the subject, as he defined academic freedom as "our freedom from external interference in": (a) who shall teach, (b) what we teach, (c) how we teach, and (d) whom we teach' (Higgins, 2001:8). The distinction between institutions aligned to the states' brand of national culture and those that were opposed to the notion, substantiates Welsh and Savage's (1977) argument that the South African higher education landscape mirrored, rather than ameliorated the social divisions which characterised society. This reality can be understood as the historical seeds that defined what Keet et al. (Chapter 3) conceptualise as \#MustFall-TheEvent. From this perspective, the notion of a Humboldtian university in South Africa signals the first challenge that can be levelled against the claim of "a public national university responsible for the education of citizens through national culture". We highlight this challenge as a mode of fostering further debate, research and inquiry into the conception of the University.

The second tension arises from the resultant question derived from this brief historical description. If the University in South Africa reflected the social cleavages that typified the apartheid state, as per Welsh and Savage's (1977) contention, can the contemporary university claim to be in service of national identity and culture? This question ignites both a Socratic and Bakhtinian dialogue while addressing the contemporary role of the University in South Africa and is reminiscent of the question that Mamdani posed at the 1993 Academic Freedom Lectures at Rhodes University. Contending that the South African academy was achieving de-racialisation, Mamdani (1993) indicates that this did not mean we were close to decolonisation. Central to his contribution was the probing of the Uses of the University, ${ }^{13}$ by asking for whom is the University and who does it serve (Mamdani, 1993). In a contemporary context, Kumalo (2020) addresses this question in what he conceptualises as a shift from vertical to horizontal accountability. If we take seriously the claim that the University is an institution in the service of broader social needs, a reflexive exercise would reveal that this lofty goal is one 
that continues to elude the academic, the administrator and maybe even the student. However, we maintain that the student might not be as delusional as the academic and the administrator as students did after all challenge the status quo that had established the University as space (an enclave perhaps) that serves the interests of a dominant middle class. With this volume suggesting that the University is on the border, it is necessary for academics and the administrators to interrogate their respective roles and positions in this institution and question its continued significance.

From the perspective of the third count of precarity - canon formation, what is the 'university on the border' to question and clarify, and how do we make decisions in this regard? Beyond simply being a training space for graduates, the University is fundamentally a space for the pursuit of knowledge and ideas. In this respect, the reader will recall that we had indicated this conception is one that also serves the ends of fostering justice through the ideas developed in this institution. Universities are places for bringing about democracy and social justice; for technological advancements and experimentation; for finding solutions to inequalities in its broadest manifestation; a space for real, meaningful and tangible partnerships; a hub for creativity, critique, including dissent.

Should this institution be committed to the futuristic project that aims at social justice through recognition, and is this to be the yardstick that determines what is to be included and excluded? Nancy Fraser's notion of social justice, where justice is viewed as a matter of fair distribution and reciprocal recognition comes to mind in this formulation (Fraser, 1995, 1997, 2001). From the recognition perspective, injustice appears in the guise of status subordination, rooted in institutionalised hierarchies of cultural value. The central paradigm underpinning injustice is misrecognition, broadly understood to encompass nonrecognition and disrespect. The remedy, therefore, is recognition of the cultural identities of groups that suffer experiences of social discrimination and exclusion. Some would argue that reconciliation has been attempted, with Mpofu (2017) claiming that the reconciliatory approach has reproduced a neoapartheid state with the majority still excluded from substantive participation in the country's economic and democratic processes. Friedman (Chapter 4) systematically analysed and augmented this point. With the canon defining 


\section{UNIVERSITY ON THE BORDER}

the University and determining national culture if we are to predicate the functionality of the 'university on the border' through a Humboldtian lens, can this institution be rooted in a historical attitude that signals a future premised in heritage and culture? Or rather should the contemporary university establish its canon on a form of republicanism? We deploy the concept of republicanism as per Readings' (1996) argument. Readings writes of the American university and its constitution of the canon that, "[the] content of the canon is grounded upon a moment of a social contract rather than the continuity of a historical tradition, and therefore is always open to revision" (1996:35). A futureoriented gaze informed by culture and heritage poses several challenges as the question of legitimacy and citizenship arises from a historical gaze. However, this challenge can be viewed as an opportunity because culture and heritage are ambiguous categories, forever contested and irreducibly discursive and changing. Following Readings' (1996) definition of the republicanism of constituting the canon gives the 'university on the border' an alternative. Staving away the constraints that come with a historical gaze that informs the future while rooting the act of canon constitution in a continuously revisionist agenda proposes a third option. The alternative proposition we suggest here combines both the historical and republican positions to create a revisionist culture grounded on a heritage of collegial (and affective) democracy; the cornerstone of the University - academic freedom. It is not merely the purely intellectual nor the ontological that matters, but the aligned value of the affective (emotion, feeling, care) and indeed active listening.

\section{ACADEMIC FREEDOM AS THE FUTURE OF THE UNIVERSITY}

We understand academic freedom as the future of the University in as much as academic freedom signifies deliberative democracy. Here we wish to note the distinction that Mazrui (1978) makes between academic freedom and academic democracy. The latter category, in its capacity to give rise to academic freedom, as deliberative democracy relies on the responses we allocate to the following questions, How widely distributed is the right to participate in decision-making? How effectively are different interests within the institution represented within the structure of power? How powerful are heads of departments, deans, the vice-chancellor, and administrative 
committees of the university? What influence do junior staff and students exercise on policymaking?

We see here, then, that academic freedom is primarily a matter of freedom from interference, whilst academic democracy concerns the right to participate (Mazrui, 1978:235).

Deliberative democracy suggests creating in the University a collegial environment, which as Mazrui (1978:235) suggests "[the] university as [an] institution [...] attained a high level of academic freedom fairly early, but until the eruption of the student revolution in the 1960s there was relatively little academic democracy". In the case of the South African university, the same holds, until the \#MustFall protests, the University in our context did little to embrace robust and scientific debate that recognises the role of the community as a constitutive element through the democratisation of knowledge production. The inclusion of the community in this way portends what Kumalo (2020) frames as horizontal accountability that takes seriously the role of the locale in which the University is situated when making knowledge claims. Deliberative democracy then, like academic freedom, is historical in its ability to create democratically conducive systems of decision-making and governance that recognise the role of the professoriate and the student, while affording each member due respect and attention in the decision-making process and governance of the University. 'Respect' and 'attention' are, in our view, attributes of the affective that drive towards self-reflexivity. For example, Alexander and Mohanty (1997:xlii) argue that in a contemporary world order structured by transnational capital "engagement based on empathy" is integral to processes of fostering 'social justice' and "building solidarity across otherwise debilitating social, economic and psychic boundaries". Empathy is not pre-given but induced as a result of context and struggle and could be viewed, by definition, as positive. Understood in shorthand as the ability to 'put oneself in the other's shoes', empathy is, what 'we' want to cultivate in ourselves and others. It is the affective attribute that we want to resurface, to define 'our' society and which we hope will characterise our interactions with those living outside our borders. ${ }^{14}$ As Ahmed (2004:29) argues, "empathy

14 See, for example, Ahmed (2004), who has explored the 'ambivalent grammar' of emotions. 


\section{UNIVERSITY ON THE BORDER}

sustains that very difference that it may seek to overcome" when subjects assume that they can feel what another feels in ways that fail to take account of differences in history, power, and experience.

It might be necessary at this juncture to consider whether this mode of deliberative engagement is not symptomatic of the self-reflexivity and internal critique of the academic suggested by Ulrike Kistner in her contribution to this collection. To frame the future of the University in this way recognises Connell's recommendation which maintains that "you cannot have a democracy in which some 'citizens' only receive decisions made by others" (1992:138). This frame suggests 'autocritique', to use Lange's framing, required of the academic and academic disciplines for them to be responsive to and engaged in decolonial praxis (that includes the affective in relation to the ontological) and not merely limit the debate to theoretical propositions. This position is further substantiated by the claim that "curricular practices involve injustice when they reduce people's capacity to remake their world" (Connell, 1992:142). Academic freedom as deliberative democracy responds to a variety of concerns that students raised during the \#MustFall protests in the country and moves away from the arresting and negative uncertainty that is the 'university on the border'. Not to say that this move rejects the positive components of uncertainty that are highlighted in Chapter 1. Rather, the idea is retaining uncertainty as a mode of ensuring democratisation that takes the agency of students as active citizens in the polis. Agency, in our view, is not simply unidirectional nor simply about action without agentic relations: it requires a dynamic interaction between various stakeholders that entail active listening and engagement with emotions.

Universities have been, since their inception, steering mechanisms for socialising society to support national and global ambitions (Newman, 1982). The University as both idea and practice is therefore in a precarious position in the current juncture. It is situated in an uneasy terrain, at the intersection of competing and contradictory paradigms caught up in the balance of power representing the intellectual model; centralised around the academic (that is, faculties, centres and curricula) as an important value versus the rival managerial demands of organisational and administrative responsibilities. It is worth reiterating that the South African university landscape is highly 
polarised, and "remains a space 'of intense sociological complexity"” (Soudien, 2008:674). Jansen (2009:208) says classrooms continue to be "deeply divided places where contending histories and rival lived experiences come [...] into the same pedagogical space". Badat (2009:457) calls this "the racist, patriarchal and authoritarian apartheid social order". Portnoi (2009:382) claims that this situation impacts on institutional culture, "based on the privilege of Whites at the expense of Blacks".

Transformation of the higher education sector through the student movement processes implies the construction of a new architecture, one far removed from 'ruins' as endpoints, which signals future orientations as new beginnings sparked by ongoing student engagement for its intrinsic and democratic value in recognising diverse perspectives within known (established) and unknown views. Sadly, despite policy changes and transformation efforts in the last twenty-five years, universities have failed to yield substantive and meaningful results, and there is a deep tension between competing views, interests and attitudes towards real, meaningful change and transformation. Rhodes (2001:48) writes in The Creation of the Future: The Role of the American University, that "Our task is to educate citizens of a new society, embracing diversity with confidence rather than escaping from it in cloistered isolation, facing the challenges of disagreement rather than sheltering from them in a capsule of silent indifference". Our contention, in closing, is that several contributors in this volume have implicitly questioned Readings' image of the 'university in ruins'. If we have identified this volume as University on the Border because the border is a utopic point of escape from totality and master narratives; a liminal space; a site of encounter; then it is also an object of knowledge. In this sense the rich and varied contributions assembled in this volume present our universities as flourishing institutions, in 'transition' rather than entities purely in a state crisis. The critical point is that a 'crisis' is not a negative in our view, nor an endpoint while it could be a turning point. Inherent in its etymology is the attendant idea of a conjuncture of both 'danger' and 'opportunity'. This volume is an intervention in the current epistemic, theoretical and methodological struggles articulated around the meaning of a transformed university. A thematic underwrites the diverse views in the featured chapters. Without homogenising insights, critical questions that precipitate further thinking and reflection include the following: What is 


\section{UNIVERSITY ON THE BORDER}

our understanding of a university? Without containing a set of prescriptions, we believe that a university is fundamentally about producing, unlocking and harnessing new knowledge, about finding new applications for existing knowledge and our collective ability to validate knowledge and values through curricula. More than that, the University is directed towards solving challenges that cross borders, modelling environments that promote dialogue, dissent and debate. Indeed, universities are spaces to instigate opportunities for social mobility by strengthening social justice and democracy (indeed helping to overcome the inequities we inherit from our past, but also to anticipate future inequities). This is a proposition we hold on to because the 'university on the border' is a strategic battleground that induces a strategy of reading that enables the reimagining of the University. 


\section{REFERENCES}

Ahmed, S. 2004. The Cultural Politics of Emotion. Edinburgh: Edinburgh University Press.

Alexander, J. \& Mohanty, C.T. (eds.). 1997. Feminist Genealogies, Colonial Legacies, Democratic Futures. New York: Routledge.

Anderson, G.M. 2002. Building a People's University in South Africa: Race, Compensatory Education, and the Limits of Democratic Reform. New York: Peter Lang Publishing.

Archer, M. 2000. Making Our Way in the World: Human Reflexivity and Social Mobility. Cambridge, UK: Cambridge University Press.

Asmal, K. 2001. The National Plan for Higher Education. Pretoria: Ministry of Education.

Badat, S. 2009. Theorising Institutional Change: Post-1994 South African Higher Education. Studies in Higher Education, 34(4):455-467. https://doi. org/10.1080/03075070902772026

Bangeni, B. \& Kapp, R. 2005. Identities in Transition: Shifting Conceptions of Home among 'Black' South African University Students. African Studies Review, 48(3):1-19. https://doi.org/ 10.1353/arw.2006.0004

Bhabha, H.K. 1994. The Location of Culture. London: Routledge.

Bhambra, G., Gebrial, D. \&Nisancioglu, K. 2018. Decolonising the University. London: Pluto Press.

Bhaskar, R. 2016. Enlightened Common Sense: The Philosophy of Critical Realism. London: Routledge. https:// doi.org/10.4324/9781315542942

Boughey, C. 2007. Educational Development in South Africa: From social reproduction to capitalist expansion? Higher Education Policy, 20:5-18. https://doi.org/10.1057/ palgrave.hep. 8300140

Boughey, C. \& McKenna, C. 2011. A MetaAnalysis of Teaching and Learning at Five Historically Disadvantaged Universities. Pretoria: Council of Higher Education.

Bozalek, V. \& Boughey, C. 2012.

(Mis)Framing Higher Education in South Africa. Social Policy and Administration, 46(6):688-703. https:// doi.org/10.1111/j.1467-9515.2012.00863.x

Christie, R. 2009. The Drama of IncomesBased Education Performance. Keynote address, the Kenton Education Conference, Stellenbosch, November 5-8.

Connell, R.W. 1992. Citizenship, Social Justice and Curriculum. International Studies in Sociology of Education, 2(2):133-146. https://doi. org/10.1080/0962021920020202

Contraband Cape Town. 2015. Luister. YouTube, August 20. https://bit.ly/ 3ydtkbG

Department of Education. 1997. Education White Paper 3: A Programme for the Transformation of Higher Education. Pretoria: DoE. https://bit.ly/33M6Y2U

Fraser, N. 1995. From Redistribution to Recognition? Dilemmas of Justice in a 'Post-Socialist' Age. New Left Review, 212(July/August):68-93.

Fraser, N. 1997. Justice Interruptus: Critical Reflections on the 'Postsocialist' Condition. New York: Routledge.

Fraser, N. 2001. Social Justice in the Knowledge Society: Redistribution, Recognition, and Participation. Contribution to the "Gut zu Wissen" Congress, Heinrich Böll Foundation, May 5. 
Freire, P. 2005 [1970]. Pedagogy of the Oppressed. New York: Continuum.

García, R. 2018. Decoloniality and the Humanities: Possibilities and Predicaments. Journal of Hispanic Higher Education, 19(3):1-15. https:// doi.org/10.1177/1538192718790045

Grosfoguel, R. 2007. The Epistemic Decolonial Turn: Beyond politicaleconomy paradigms. Cultural Studies, 21(2\&3):211-223. https://doi. org/10.1080/09502380601162514

Grosfoguel, R. 2013. The Structure of Knowledge in Westernized Universities: Epistemic Racism/Sexism and the Four Genocides/Epistemicides of the Long 16th Century. Human Architecture: Journal of the Sociology of SelfKnowledge, 11(1):73-90.

Habib, A. 2016a. Goals and Means: reimagining the South African University and critically analysing the struggle for its realisation. Transformation, 90:111-132. https://doi. org/10.1353/trn.2016.0006

Habib, A. 2016b. Transcending the Past and Reimagining the Future of the South African University. Journal of Southern African Studies, 42(1):35-48. https://doi. org/10.1080/03057070.2016.1121716

Habib, A. 2019. Rebels and Rage: Reflecting on \#FeesMustFall. Johannesburg: Jonathan Ball Publishers.

Heleta, S. 2016. Decolonisation of Higher Education: Dismantling Epistemic Violence and Eurocentrism in South Africa. Transformation in Higher Education, 1(1):1-8. https://doi.org/ 10.4102/the.vli1.9

Higgins, J. 2001. Academic Freedom in the New South Africa. Safundi, 2(2):1-19. https://doi.org/10.1080/175331701 00702207
Hinchmann, E.S. 2005. Telling as Inviting to Trust. Philosophy and Phenomenological Research, 70(3):562-587. https://doi.org/ 10.1111/j.1933-1592.2005.tb00415.x

Isin, E.F. \& Turner, B.S. 2007. Investigating Citizenship: An Agenda for Citizenship Studies. Citizenship Studies, 11(1):5-17. https://doi.org/10.1080/136210206 01099773

Jansen, J.D. 2009. Knowledge in the Blood: Confronting Race and the Apartheid Past. Palo Alto, California: Stanford University Press. https://doi. org/10.1515/9780804771160

Kapp, R. \& Bangeni, B. 2011. A longitudinal study of students' negotiation of language, literacy and identity. Southern African Linguistics and Applied Language Studies, 29(2):197-208. https://doi.org/10.29 89/16073614.2011.633366

Kerr, C. 1963. The Uses of the University. Cambridge, Massachusetts: Harvard University Press.

Kumalo, S.H. 2018a. Epistemic Justice through Ontological Reclamation in pedagogy: Detailing Mutual (In)Fallibility using Inseparable Categories. Journal of Education, 72:4-19. https://doi.org/10.17159/25209868/i72a01

Kumalo, S.H. 2018b. Explicating Abjection - Historically White Universities Creating Natives of Nowhere? Critical Studies in Teaching and Learning (CriSTaL), 6(1):1-17. https://doi.org/ 10.14426/cristal.v6i1.132

Kumalo, S.H. 2020. Justice through Higher Education: Revisiting the White Paper 3 of 1997. Higher Education Quarterly. https://doi.org/10.1111/hequ.12253 
Kumalo, S.H. (ed.). 2021. Decolonisation as Democratisation: Global Insights into the South African Experiences. Cape Town: HSRC Press.

Lebakeng, J.T., Phalane, M.M. \& Nase, D. 2006. Epistemicide, Institutional Cultures and the Imperative for the Africanisation of Universities in South Africa. Alternation, 13(1):70-87.

Luckett, K. 2010. Knowledge claims and codes of legitimation: Implications for curriculum recontextualisation in South African Higher Education. Africanus, 401(1):4-18.

Mamdani, M. 1993. University Crisis and Reform: A Reflection on the African Experience. Review of African Political Economy, 58:7-19. https://doi. org/10.1080/03056249308704016

Margolis, E. (ed.). (2001). The Hidden Curriculum in Higher Education. New York: Routledge. https://doi. org/10.4324/9780203901854

Maseko, P. \& Vale, P. 2016. The Struggle over African Languages. Arts and Humanities in Higher Education, 15(1):79-93. https://doi. org/10.1177/1474022215613605

Mazrui, A.A. 1978. Political Values and the Educated Class in Africa. London: Heinemann.

Mkhize, N. 2016. Away with Good Bantus: De-linking African Language Literature from Culture, 'Tribe' and Propriety. Arts and Humanities in Higher Education, 15(1):146-152. https://doi. org/10.1177/1474022215613600

Mpofu, S. 2017. Disruption as a communicative strategy: The case of \#FeesMustFall and \#RhodesMustFall students' protests in South Africa. Journal of African Media Studies,
9(2):351-377. https://doi.org/10.1386/ jams.9.2.351_1

Newman, J.H. 1982. The Idea of a University. Notre Dame, Indiana: University of Notre Dame Press.

Nyoka, B. 2013. Negation and Affirmation: A Critique of Sociology in South Africa. African Sociological Review, 17(1):2-24.

Orwell, G. 2008 [1987]. Animal Farm. Cape Town: Maskew Miller Longman.

Popkewitz, T.S. \& Brennan, M. 1997. Restructuring of Social and Political Theory in Education: Foucault and a Social Epistemology of School Practices. Educational Theory, 47(3):287-313. https://doi.org/10.1111/j.1741-5446.19 97.00287.x

Popkewitz, T.S. \& Brennan, M. (eds.). 1998. Foucault's Challenge Discourse, Knowledge, and Power in Education. New York: Columbia University Press.

Portnoi, L. 2009. Transformative Change? Institutional Formalities and Institutional Realities. South African Journal of Higher Education, 23(2):373-385.

Readings, B. 1996. The University in Ruins. Cambridge, Massachusetts: Harvard University Press.

Rhodes, F.H.T. 2001. The Creation of the Future: The Role of the American University. Ithaca, New York: Cornell University Press.

Rustin, M. 2016. The Neoliberal University and Its Alternatives. Soundings, 63: 147-170. https://doi.org/10.3898/13 6266216819377057

Ruth, D. 2006. Identity, Institutions and Systemic Change: The Case of Higher Education in South Africa. Educational 


\section{UNIVERSITY ON THE BORDER}

Management Administration \& Leadership, 34(4):487-510. https://doi. org/10.1177/1741143206068213

Seepe, S. 2017. Higher Education Transformation in South Africa. In: M. Cross \& A. Ndofirepi (eds.). Knowledge and Changer in African Universities. Rotterdam: Sense Publishers. https://doi.org/10.1007/ 978-94-6300-842-6_8

Shay, S. 2015. Curriculum Reform in Higher Education: A Contested Space. Teaching in Higher Education, 20(4):431-444. https://doi.org/10.1080/13562517.20 15.1023287

Soudien, C. 2008. The Intersection of Race and Class in the South African University: Student Experiences. South African Journal of Higher Education, 22(3):662-678. https://doi.org/10.4314/ sajhe.v22i3.25809

Thepa, M. 2016. Real victims of student uprisings are the poor. Sunday Independent, January 17. https://www. iol.co.za/sundayindependent/realvictims-of-student-uprisings-are-thepoor-1971992

Turner, B.S. 2001. The Erosion of Citizenship. British Journal of Sociology, 52(2):189-209. https://doi. org/10.1080/00071310120044944
Van Heerden, E.M. 1999. My School, your school, our school? Issues of attitude, behaviour and identity among black and white pupils in desegregated South African schools. South African Journal of Ethnology, 22(2):67-80.

Van Wyk, B. \& Higgs, P. 2011. The Curriculum in an African Context. Indilinga: African Journal of Indigenous Knowledge Systems, 10(2):171-181.

Welsh, D. \& Savage, M. 1977. The universities in divided societies: The case of South Africa. In: H. van der Merwe \& D. Welsh (eds). The future of the university in South Africa. Cape Town: David Phillip. 130-147.

Wicomb, Z. \& Van der Vlies, A. (ed.). 2018. Race, Nation, Translation: South African Essays, 1990-2013. Johannesburg: Wits University Press. https://doi. org/10.2307/j.ctv7cjw60

Wortham, S. 1999. Rethinking the University: Leverage and Deconstruction. New York: Manchester University Press.

Zondi, M. 2020. Resurrecting the 'Black Archives': Revisiting Benedict Wallet Vilakazi with a Focus on the Utility and Meaning of African Languages and Literatures in Higher Education. Education as Change, 24(4626). https:// doi.org/10.25159/1947-9417/4626 